\title{
HUKUM KONSTITUSI SEBAGAI SUATU ILMU
}

\author{
Astim Riyanto ${ }^{1}$
}

\section{Abstrak}

The Law of the Constitution as a science, because all of qualification of a knowledge become a science that self-exist was fulfilled. Qualification of a knowledge become a science that self-exist meant, that are to has self-object study, has self-method, has utilities value, systematic piled up, logic dissection, has the character of universal, has special senses, and is supported by their experts/ scholars. The Law of the Constitution as a science, its the way is begun from investigation of Aristotle (384-322 B.C.) to 158 constitutions city states from 186 city states ancient Greece. The result of investigation, he is poured out in a book of Politics. There are four chapters that in connection with constitution form eight chapters of the book. Then, the result of Aristotle's investigation, 23 centuries moreover was faithfulled by Albert Venn Dicey (1835-1922) in a book of An Introduction to Study of The Law of The Constitution (1885). Concerning books the others about constitutions that was written by their authors more give a shape of Bases of The Law of The Constitution than scientific of The Law of the Constitution. In 2007 or 122 years later (1885-2007), through presentation a paper that the title is The Law of the Constitution is a part of Constitutional Law, I declare The Law of the Constitution as a science, that self-exist with name is Science of The Law of the Constitution.

Kata kunci: hukum konstitusi, konstitusi, ilmu hukum konstitusi.

\section{Pendahuluan}

Sejak abad ke-4 sebelum Masehi (sM) atau selama 24 abad Hukum Konstitusi menapaki perjalanannya sebagai suatu pengetahuan menuju menjadi suatu ilmu yang berdiri sendiri. Sejak paruh kedua abad ke-17

1 Penulis adalah Guru Besar Ilmu Hukum Tata Negara spesialisasi Hukum Konstitusi, Doktor Hukum Tata Negara dan Magister Hukum Tata Negara spesialisasi Hukum Konstitusi dari Universitas Padjadjaran (UNPAD) Bandung, Sarjana Pendidikan Kewarganegaraan dan Hukum dari Institut Keguruan dan Ilmu Pendidikan (IKIP) Bandung, Sarjana Hukum Pidana dari Universitas Islam Nusantara (UNINUS) Bandung, Dosen Teori dan Hukum Konstitusi serta Kepala Divisi Hukum pada Universitas Pendidikan Indonesia (UPI) di Bandung. Bukunya antara lain Teori Konstitusi (1993, 2000, 2006). 
pengetahuan Hukum Konstitusi mengalami tonggak perkembangan yang menonjol yang ditandai dengan lahirnya Konstitusi di Inggris yang diberi nama The Instrument of Government of 1653. Atau secara lengkap dapat disebut "The Instrument of Government" of The United Kingdom of Great Britain and Northern Ireland of 1653 yang berlaku hingga 1660. Namun, sejak paruh kedua abad ke-18 Hukum Konstitusi mengalami perkembangan yang signifikan ditandai dengan lahirnya Konstitusi modern pertama di dunia yang hingga sekarang masih berlaku, yaitu The Constitution of United States of America of 1787.

Sejak 6 Agustus 2007 oleh penulis pengetahuan Hukum Konstitusi dideklarasikan melalui presentasi makalah dengan judul Hukum Konstitusi Bagian Dari Hukum Tata Negara dalam suatu komunitas akademisi di suatu kampus perguruan tinggi Indonesia sebagai suatu ilmu yang berdiri sendiri. ${ }^{2}$ Oleh karena itu, dalam uraian ini Hukum Konstitusi diposisikan/diangkat sebagai suatu ilmu baru cabang dari Ilmu HTN dalam arti luas. Dengan lahirnya ilmu baru ini, maka Ilmu HTN dalam arti luas tersebut menjadi memiliki tiga cabang ilmu, yaitu Ilmu Hukum Konstitusi, Ilmu Hukum Tata Negara dalam arti sempit, dan Ilmu Hukum Tata Usaha Negara (HTUN)/Hukum Administrasi Negara (HAN). Dalam paparan ini diuraikan Hukum Konstitusi sebagai Suatu Ilmu.

\section{Persyaratan Suatu Ilmu Berdiri Sendiri}

Persyaratan suatu ilmu berdiri sendiri dapat dikelompokkan ke dalam dua kelompok persyaratan, yaitu persyaratan suatu ilmu dari segi filsafat ilmu dan persyaratan ilmu yang lain.

\section{A. Persyaratan Suatu Ilmu dari Segi Filsafat Ilmu}

Dilihat dari segi filsafat ilmu, mensyaratkan suatu ilmu yang berdiri sendiri harus memenuhi segi ontologi, segi epistemologi, dan segi aksiologi ${ }^{3}$; maka Hukum Konstitusi dapat memenuhinya.

${ }^{2}$ Lihat Astim Riyanto, Hukum Konstitusi Bagian Dari Hukum Tata Negara, Makalah, Di-presentasikan di depan komunitas akademisi Fakultas Pendidikan Ilmu Pengetahuan Sosial (FPIPS) Universitas Pendidikan Indonesia (UPI) dalam rangka Dr.Astim Riyanto,SH,MH. memperoleh Jabatan Guru Besar Tetap dalam Bidang Ilmu Hukum Tata Negara spesialisasi Hukum Konstitusi pada FPIPS UPI di Bandung, Bandung, 6 Agustus 2007, hal. 8 . 


\section{Segi Ontologi Hukum Konstitusi}

Hukum Konstitusi dilihat dari segi ontologi mempunyai obyek studi sendiri. Obyek studi Hukum Konstitusi adalah konstitusi (ditulis dengan huruf k kecil). Obyek studi konstitusi dalam konteks Ilmu Hukum Konstitusi adalah konstitusi dalam arti luas dan konstitusi dalam arti sempit. Konstitusi dalam arti luas adalah Hukum Dasar tertulis dan Hukum Dasar tidak tertulis. Hukum Dasar tertulis terdiri atas Hukum Dasar tertulis dalam arti luas dan Hukum Dasar tertulis dalam arti sempit. Hukum Dasar tertulis dalam arti luas terdiri atas peraturan perundang-undangan konstitutif atau peraturan-peraturan legal konstitutif meliputi Undang-Undang Dasar (UUD), Undang-Undang (UU) bermuatan konstitusi, UU organik, UU non organik, Peraturan Pemerintah Pengganti Undang-Undang (Perpu), Peraturan Pemerintah (PP), Peraturan Presiden (Perpres), Peraturan Menteri (Permen), Peraturan Daerah (Perda), Peraturan Kepala Daerah, peraturan pelaksanaan, peraturan kebijakan, dan peraturan khusus terutama dalam lapangan ketatanegaraan. Konstitusi dalam arti sempit atau Hukum Dasar tertulis dalam arti sempit adalah "UUD" atau "Konstitusi" (ditulis dengan huruf $\mathrm{K}$ besar). Hukum Dasar tidak tertulis terdiri atas peraturan-peraturan non legal konstitutif meliputi peraturan kebiasaan (usages rules), peraturan kesepahaman/kesepakatan (understandings rules), peraturan adat istiadat (customs rules), dan peraturan konvensi (conventions rules $)^{4}$ terutama dalam lapangan ketatanegaraan.

Setiap ilmu yang telah berdiri sendiri mempunyai obyek material dan obyek formal. Demikian pula Ilmu Hukum Konstitusi. Obyek material Ilmu Hukum Konstitusi adalah konstitusi, sedangkan obyek formal Ilmu Hukum Konstitusi adalah Hukum Dasar. Obyek material "konstitusi" di samping dipelajari oleh Ilmu Hukum Konstitusi, juga dipelajari oleh ilmuilmu lain, yaitu Ilmu HTN dalam arti luas, Ilmu HTN dalam arti sempit, Ilmu HTUN/HAN, Ilmu Politik, dan Sosiologi. Ilmu Hukum Konstitusi mempelajari konstitusi sebagai hukum dasar,

${ }^{3}$ Lihat Achmad Sanusi, "Pengantar Ilmu Hukum dan Pengantar Tata Hukum Indonesia”, (Bandung: CV. Tarsito, 1984), hal. 15-16.

${ }^{4}$ Lihat Kenneth C.Wheare, Modern Constitutions, Third Impression, First Published 1951, (Oxford University Press, London, New York, Toronto, 1975), hal. 1. 
Ilmu HTN dalam arti luas mempelajari konstitusi sebagai hukum organisasi negara, Ilmu HTN dalam arti sempit mempelajari konstitusi sebagai hukum susunan negara, Ilmu HTUN/HAN mempelajari konstitusi sebagai hukum penyelenggaraan negara, Ilmu Politik mempelajari konstitusi sebagai keputusan politik tertinggi, dan Sosiologi mempelajari konstitusi sebagai institusi sosial.

Menurut J.G.Steenbeek sebagaimana disitir oleh R.Sri Soemantri Martosoewignjo, pada umumnya konstitusi sebagai hukum dasar berisi tiga hal pokok, yaitu : (1) adanya jaminan terhadap hak-hak asasi manusia dan warga negara, (2) ditetapkannya susunan ketatanegaraan suatu negara yang bersifat fundamental, serta (3) adanya pembagian dan pembatasan tugas ketatanegaraan yang juga bersifai fundamental. ${ }^{5}$

\section{Segi Epistemologi Hukum Konstitusi}

Hukum Konstitusi dilihat dari segi epistemologi mempunyai metode sendiri. Melalui metode sendiri dengan memanfaatkan tangkapan pancaindera, rasio, dan pengetahuan siap, dengan cara membaca, menulis, meneliti, dan tukar pikiran/ pengalaman, seorang ilmuwan akan memperoleh bahan untuk menumbuhkembangkan suatu ilmu termasuk Ilmu Hukum Konstitusi. Secara umum, Ilmu Hukum Konstitusi dapat menggunakan metodemetode yang lazim dipakai oleh berbagai ilmu, yaitu metode deduksi (deduktif), induksi (induktif), eduksi (eduktif), dan abduksi (abduktif). Secara khusus, Ilmu Hukum Konstitusi dapat menggunakan metode-metode, yaitu metode filosofis-konstitutif, metode yuridis-konstitutif, dan metode empiris-konstitutif. Metode filosofis-konstitutif terdiri atas metode kontemplatifkonstitutif, metode spekulatif-konstitutif, dan metode deduktifkonstitutif. Metode yuridis-konstitutif terdiri atas metode yuridis normatif-konstitutif, metode yuridis historis-konstitutif, dan metode yuridis komparatif-konstitutif. Metode empiris-konstitutif terdiri atas metode empiris sosiologis-konstitutif dan metode empiris yuridis-konstitutif.

5 Lihat R.Sri Soemantri Martosoewignjo, "Prosedur dan Sistem Perubahan Konstitusi", Cetakan IV, (Bandung: PT. Alumni, 1987), hal. 51. 


\section{Segi Aksiologi Hukum Konstitusi}

Hukum Konstitusi dilihat dari segi aksiologi mempunyai nilai kegunaan. Nilai kegunaan Hukum Konstitusi terdiri atas nilai kegunaan teoretis dan nilai kegunaan praktis. Nilai kegunaan Hukum Konstitusi teoretis dalam pembentukan negara, penentuan norma dasar dan simbol-simbol kenegaraan, penentuan cita-cita dan tujuan negara, penentuan organisasi negara, penataan organisasi negara, perlindungan hak asasi manusia dan warga negara, dan penjaminan kemakmuran/ kesejahteraan individu/bersama/umum. Nilai kegunaan Hukum Konstitusi praktis dalam penjaminan kesatuan dan persatuan bangsa atau persatuan dan kesatuan bangsa, penyelenggaraan pemerintahan, penyelenggaraan hubungan antarnegara, penyelenggaraan pertahanan dan keamanan, penyelenggaraan demokrasi, penegakan hukum dalam negara dalam hal ini dalam negara hukum, dan memecahkan masalah-masalah kenegaraan/ketatanegaraan. Baik terhadap nilai kegunaan Hukum Konstitusi teoretis maupun terhadap nilai kegunaan Hukum Konstitusi praktis, konstitusi berfungsi membatasi dan mengendalikan penyelenggara negara i.c. penyelenggara pemerintahan agar penyelenggaraan negara i.c. penyelenggaraan pemerintahan berjalan ke arah pencapaian cita-cita dan tujuan negara.

\section{B. Persyaratan Ilmu yang Lain}

Di samping dilihat dari tiga segi filsafat ilmu di atas, dari sudut pandang ilmu, suatu pengetahuan dapat dikategorikan ke dalam suatu ilmu berdiri sendiri jika juga memenuhi persyaratan ilmu yang lain, yaitu tersusun sistematis, uraian logis, bersifat universal, memiliki pengertian-pengertian khusus, dan didukung para ahli/pakar.

\section{Hukum Konstitusi Tersusun Sistematis}

Sistematika yang sekaligus menunjukkan batang tubuh pengetahuan suatu ilmu termasuk sistematika yang sekaligus menunjukkan batang tubuh pengetahuan Hukum Konstitusi secara garis besar dapat dilihat dari sistematika Pengantar Ilmu yang bersangkutan. Pengantar Ilmu Hukum Konstitusi dapat meliputi 13 bab, yaitu Bab I Pendahuluan, Bab II Pengertian Ilmu Hukum Konstitusi, Bab III Eksistensi Ilmu Hukum Konstitusi, Bab IV 
Metode Ilmu Hukum Konstitusi, Bab V Hubungan Ilmu Hukum Konstitusi dengan Ilmu-ilmu Lain, Bab VI Konstelasi Ilmu Hukum Konstitusi, dan Bab VII Pembidangan Ilmu Hukum Konstitusi. Dalam pembidangan Ilmu Hukum Konstitusi dapat dikembangkan Hukum Pembentukan Negara, Hukum LembagaLembaga Negara, Hukum Badan-Badan Negara, Hukum Pemerintahan Negara, Hukum Bagian Negara, Hukum Substansi Konstitusi Negara, dan Hukum Regulasi Negara. Selanjutnya, Bab VIII Hukum Perjanjian Antar Negara dalam Perspektif Hukum Konstitusi, Bab IX Hukum Publik dan Privat dalam Perspektif Hukum Konstitusi, Bab X Hukum Buatan Negara, Perseorangan, dan Perkumpulan dalam Perspektif Hukum Konstitusi, Bab XI Sumber Hukum Konstitusi, Bab XII Hukum Material dan Formal Konstitusi, dan Bab XIII Penafsiran dan Konstruksi Hukum Konstitusi. Bab-bab tersebut dirinci lagi ke dalam sub-sub bab dan seterusnya.

\section{Uraian Hukum Konstitusi Logis}

Baik dilihat dari segi batang tubuh pengetahuan Hukum Konstitusi, pengantar Ilmu Hukum Konstitusi, maupun pembidangan Ilmu Hukum Konstitusi menunjukkan uraian yang logis. Logis (logical $)^{6}$ dalam arti sesuai dengan logika ${ }^{7}$ atau mantik (mantiq). ${ }^{8}$ Pakar HTN Albert Venn Dicey (1835-1922) dari Inggris telah menampilkan kerangka umum Hukum Konstitusi dalam buku beliau Pengantar Studi Hukum Konstitusi yang pertama kali terbit 1885. Dalam materi buku tersebut terdiri atas Tiga Bagian, yaitu Bagian I Kedaulatan Parlemen, Bagian II

6 Lihat Departemen Pendidikan dan Kebudayaan RI, Kamus Besar Bahasa Indonesia, Edisi Kedua, Cetakan Ketiga, PN. Balai Pustaka, Jakarta, 1994, hal. 599, mengartikan logis ialah benar menurut penalaran atau masuk akal.

7 Lihat Irving M.Copi, "Introduction to Logics", Fifth Edition, Macmillan Publishing Co., New York, 1978, hal. 3, dalam Mundiri, Logika, Cetakan Ketiga (Cetakan Pertama 1994), PT. Raja Grafindo Persada, Jakarta, 1998, hal. 2, merumuskan : "Logika adalah ilmu yang mempelajari metode dan hukum-hukum yang digunakan untuk membedakan penalaran yang betul dari penalaran yang salah".

${ }^{8}$ Thaib Thahir A.Mu'in, "Ilmu Mantiq", Widjaya, Jakarta, 1966, hal. 16, dalam Drs. Mundiri, idem., memberikan batasan mantik (mantiq) : "Ilmu untuk menggerakkan pikiran kepada jalan yang lurus dalam memperoleh suatu kebenaran". 
Negara Hukum, dan Bagian III Hubungan Antara Hukum Konstitusi dan Konvensi Konstitusi.

\section{Hukum Konstitusi Bersifat Universal}

Hukum Konstitusi bersifat universal, dapat dilihat dari ungkapan R.Sri Soemantri Martosoewignjo yang mengatakan apabila dilakukan penyelidikan nyatalah pada kita, tidak ada satu negara pun di dunia sekarang ini yang tidak mempunyai konstitusi. Dengan demikian, dapat dikatakan negara dan konstitusi merupakan dua lembaga yang tidak dapat dipisahkan satu dengan yang lain. Ditetapkannya konstitusi kemudian setelah adanya negara tidak berarti dapat dipisahkannya kedua lembaga tersebut. ${ }^{9}$

Max Boli Sabon mengatakan dikenal dua fungsi utama konstitusi, yaitu : (1) fungsionalisasi konstitusi sebelum suatu negara dibentuk (fungsi a-priori) dan (2) fungsionalisasi konstitusi setelah suatu negara dibentuk (fungsi a-posteriori). Dalam fungsinya yang pertama, konstitusi dipandang sebagai hasil perjanjian masyarakat untuk membentuk negara. Dalam fungsinya yang kedua, konstitusi dipandang se-bagai akte pendirian negara (constitution as a birth certificate) sebagai bukti bahwa organisasi politik yang namanya "negara" itu adalah suatu badan hukum yang layak bertindak dalam lalu lintas hukum. Kedua fungsi konstitusi inilah yang dimaksud dengan "fungsi ganda konstitusi". ${ }^{10}$ Mengenai konstitusi dipandang sebagai akte pendirian negara, Henc van Maarseveen dan Ger van der Tang mengemukakan: ${ }^{11}$

Often, a newly formed state uses its constitution more or less as a birth certificate. To possess a constitution is regarded as a sign of adulthood and independence. It is as it were the letter of credence which a country

${ }^{9}$ Lihat R.Sri Soemantri Martosoewignjo, Op. Cit., hal. 1-2.

${ }^{10}$ Lihat Max Boli Sabon, Fungsi Ganda Konstitusi Suatu Jawaban Alternatif Tentang Tepatnya Undang-Undang Dasar 1945 Mulai Berlaku, (Bandung: PT. Grafttri, 1991), hal. 17-18.

11 Henc van Maarseveen and Ger van der Tang, "Written Constitutions, A. Computerized Comparative Study", (Ocean Publications, Inc., Dobbs Ferry, New York, 1978), hal. 3. 
presents to the international community as a taken of its independence and souvereignty.

Menurut mereka, kerapkali, suatu negara baru dibentuk konstitusinya digunakan lebih atau kurang sebagai sertifikat (akte) kelahirannya. Negara yang memiliki suatu konstitusi dihormati sebagai suatu tanda kedewasaan dan kemerdekaan. Sertifikat (akte) itu sebagai surat kepercayaan suatu negara hadir ke masyarakat internasional sebagai suatu tanda menerima kemerdekaan dan kedaulatannya.

\section{Hukum Konstitusi Memiliki Pengertian-pengertian Khusus}

Pengertian-pengertian khusus dari suatu ilmu termasuk Ilmu Hukum Konstitusi tercermin dari peristilahan atau istilah-istilah dalam ilmu yang bersangkutan. Hukum Konstitusi telah memiliki istilah-istilah yang sudah lazim dipergunakannya. Guna menunjukkan bahwa dalam Hukum Konstitusi telah memiliki istilah-istilah dengan pengertiannya sendiri-sendiri, maka pada kesempatan ini diketengahkan istilah-istilah yang dipergunakan oleh empat sarjana yang dapat dipandang ahli/pakar Hukum Konstitusi, yaitu Albert Venn Dicey, C.F.Strong, dan Kenneth C.Wheare dari Inggris serta Jacques Godechot dari Perancis dalam Perancis dalam bukunya masing-masing.

Dalam bukunya An Introduction to Study of The Law of The Constitution (1885), Albert Venn Dicey ${ }^{12}$ (1835-1922) antara lain menyebutkan istilah-istilah mengenai konstitusi (constitution), yaitu constitution, constitutionalism, the law of the constitution, the conventions of the constitution, the study of the law of the constitution, the existing constitution, constitutional ideas, constitutional system, change of the constitution, constitutional statutes, modern constitution, constitutional rights, constitutional practice, constitutional rule, constitutional reformers, constitutional problems, natural constitution, the form of the constitution, constitutionalists, constitutional history, constitutional government, the practice of the constitution, existence of the constitution, constitutional morality,

12 Lihat Albert Venn Dicey, An Introduction to Study of The Law of The Constitution, Tenth Edition (First Edition 1885), (London: English Language Book Society and Macmillan, 1952), hal. 1-397. 
constitutional maxim, written or statutory constitution, unwritten constitution, teachers of constitutional law, matters of constitutional law, the constitution of ordinary law, constitutional laws, the constitutionality of the laws, the constitutionality acts, constitutionality of the legislation, constitutional or fundamental laws, constitutionally the right to change the constitutional, the constitutional laws, constitutional amendement the constitutional laws, a particular constitutional provision, flexible constitution, rigid constitution, foreign constitution, maker of constitution, constitutional powers, preamble constitution, state constitution, supremacy of constitution, constitutional jurisprudence, constitution guarantee, fundamental principle of constitution, main provisions of constitution, constitutional theories, constitutional force, principles of constitutional morality, constitutional precedents, fundamental principles of constitution, existing constitution, constitutional innovations, dan constitutional powers.

Dalam bukunya Modern Political Constitutions An Introduction to the Comparative Study of Their History and Existing Form (1930), C.F.Strong ${ }^{13}$ antara lain menyebutkan istilah-istilah mengenai konstitusi (constitution), yaitu the constitution, the constitutional state, the Constitutional Influence, National Constitutionalism, classification of constitutions, the Constitution Applies, the nature of the constitution, constitutional legislation, modern constitutional states, the constitutional powers, a constitution consisting of organs, the objects of a constitution, the roots of political constitutionalism, constitutional principles, the contemporary constitutional state, the rise of the constitutional state, modern constitutionalism, the national constitutional state, republican constitution, mediaeval constitutionalism, matter of constitutional interest, development of the constitution, development of constitutionalism, statutory law of the Constitution, constitutional development, subvert the constitution, basic constitution, founded upon a constitution, constitution embodies, the promulgation of a political constitution, development of modern documentary

13 Lihat C.F.Strong, "Modern Political Constitutions An Introduction to the Comparative Study of Their History and Existing Form", Fifth (Revised) Edition 1958, Second Impression (First Printed 1930), (London: Sidgwick \& Jackson Limited, 1960), hal. v$\mathrm{x}, 1-352$. 
constitutionalism, constitutional monarchy, constitutions promulgated, changes on constitutional lines, national constitutionalism, existing constitution, great surge of constitutionalism originated, progressive constitutional state, the national constitutional experiment, attempts at constitutionalisation, foundation for constitutional rights, democratic constitutionalism, constitutional safeguards, maintenance of the constitution, the bounds of the constitution, evolution of modern constitutionalism, modern constitutional states, constitution-makers, considerably modified the Constitution, a law of the Constitution, modern constitutional state, modern constitutional politics, the constitution is a treaty, the Constitution establishes, limits of the Constitution, the State Constitutions, constitutional amendment, the Constitution comparable, constitutional amendment, the constitutional theory, constitutional document, constitutional law, constitutional changes, constitutional laws, constitutional character, constitutional acts, ancient constitution, constitutional life, constitutional forms, the law of the constitution, the conventions of the constitution, constitutional legislation, elements of the constitution, constitutional revision, the basis of the constitution, constitutional changes, existing documentary constitutions, modern constitutional state, constitutions promulgated, constitutional acts, original Constitution, constitutional ideas, constitutional government, constitutional state, maxims of constitutionalism, constitutional law-making, safeguard the Constitution, constitutional issues, political constitutionalism, constitution of the League, constitutional development, dan national democratic constitutionalism.

Dalam bukunya Modern Constitutions (1951), Kenneth C. Wheare $^{14}$ antara lain menyebutkan istilah-istilah mengenai konstitusi (constitution), yaitu constitution, constitution change, constitutional government, the amendment of the Constitution, constitutional rules of law, the origins of modern Constitutions, amendment of the Constitution, framers of Constitution, demand the Constitution, Constitution supreme, frame Constitutions, work framing Constitutions, the law of a Constitution, need protection in a Constitution, binding Constitution, supreme Constitution, constitutional convention, classification of Constitution, alteration

${ }^{14}$ Lihat Prof.Kenneth C.Wheare, Op. Cit., hal. 1-142. 
in the Constitution, supremacy of the Constitution, principle Constitutions, actual Constitution, modern Constitution makers, form of Constitution, framers of the Constitution, Constitution declares, Constitution guaranteed, authority a Constitution, criterion the Constitution, examination of Constitution, the nature or meaning of a Constitution, recognized or safeguarded in Constitutions, constitutional change, growth and strength of a Constitution depends, modifying a Constitution, the law of the Constitution, interpretation of the Constitution, the requirements of a Constitution, the law of a Constitution, constitutional law, dan Constitutional Government.

Dalam bukunya Les Constitutions de la France Depuis 1789, Jacques Godechot ${ }^{15}$ (1982), antara lain menyebutkan istilah-istilah mengenai "konstitusi" (constitution), yaitu de constitutions, grand nombre de constitutions, quinze constitutions, cependant chacune de ces constitutions, lecture de ces constitutions, prēcēdant chacune des constitutions, point de vue constitutionnel, de constitution ècrite, adoptē des constitutions, l' exēcution de la constitution, encore de la Constitution, rēdiger la constitution, la constitution devra, plupart des constitutions, autres constitutions, mème dire que les constitutions, original de l'histoire constitutionnelle, constitutions et documents politiques, droit constitutionnel, les origines des constitutions, ètudes sur les constitutions de l'éroque rēvolutionnaire, etablisment et rēvision de constitutions, les diffērentes constitutions, le pouvoir exēcutive dans la constitution, la constitution girondine, plēbiscite sur la constitution, propos de la constitution montagnarde, pouvoir lègislatif et la constitution, origines du rēfērendum dans la constitution, notion de constitution, pouvoir exēcutif dans la constitution, l'élaboration de la charte constitutionnelle, la constitution sēnatoriale, l'acte additionnel aux constitutions, pouvoir lëgislatif dans la constitution, preparation de la constitution, l'evolution constitutionnelle, la signification constitutionnelle, gambetta et la constitution, le rēgime constitutionnel, les modifications de la constitution, le problēme de la rēvision constitutionnelle, les actes et projets constitutionnels, actes constitutionnels, dan institutions politiques et droit constitutionnel.

${ }^{15}$ Lihat Jacques Godechot, "Les Constitutions de La France Depuis 1789", (Paris: Garnier-Flammarion, 1982), hal. 5-508. 
Dari istilah-istilah mengenai konstitusi dalam empat buku dari empat pengarang tentang konstitusi tersebut di atas sebagai sampel, dapat ditarik kesimpulan: (1) telah banyak ditampilkan istilah-istilah konstitusi, (2) istilah-istilah konstitusi yang dibuat oleh keempat pengarang itu pada umumnya mengandung persamaan, dan (3) dari istilah-istilah konstitusi tadi menggambarkan cakupan pembahasan Hukum Konstitusi.

\section{Hukum Konstitusi Didukung Para Ahli/Pakar}

Suatu ilmu akan eksis jika didukung para ahli/pakar ilmu yang bersangkutan. Demikian pula Ilmu Hukum Konstitusi sejak pertumbuhannya hingga perkembang-annya sekarang didukung para ahli/pakarnya. Sejumlah nama yang telah menuang-kan buah pikirannya mengenai konstitusi, melalui karya tulis berupa buku ataupun non buku dapat disebut, baik dari dalam maupun dari luar negara Indonesia yang dipandang telah berjasa dalam menumbuhkembangkan Hukum Konstitusi hingga menjadi Studi Hukum Konstitusi dan kemudian menjadi Ilmu Hukum Konstitusi.

Sejumlah nama dari luar Indonesia yang dipandang telah berjasa dalam menumbuhkembangkan Hukum Konstitusi hingga menjadi suatu Studi Hukum Konstitusi dan kemudian menjadi Ilmu Hukum Konstitusi antara lain Aristoteles dari Yunani kuno; Albert Venn Dicey, Bolingbroke, Lord James Bryce, Sir William Ivor Jennings, C.F.Strong, dan Kenneth C.Wheare dari Inggris; Lafayette, Leon Duguit, Maurice Hauriou, dan Jacques Godechot dari Perancis; Carl Schmitt dan Hermann Heller dari Jerman, Hans Kelsen dari Austria; A.A.H.Struycken, A.F. de Savornin Lohman, L.J.van Apeldoorn, Henc van Maarseveen, dan Ger van der Tang dari Belanda; Alexander Hamilton, James Madison, John Jay, Wallace S.Sayre, Walter F.Murphy, James E.Fleming, dan Sotirios A.Barber dari Amerika Serikat; Andrei Y.Vyshinsky dari Uni Soviet; Naoki Kobayashi dari Jepang; Subhi Rajab Mahmassani dari Libanon; serta Carmelo V.Sison dan Luz D.Pagulayan dari Filipina.

Sejumlah nama dari dalam negara Indonesia yang dipandang telah berjasa dalam menumbuhkembangkan Hukum Konstitusi hingga menjadi suatu Studi Hukum Konstitusi dan kemudian menjadi Ilmu Hukum Konstitusi antara lain Muhammad Yamin, Djokosoetono, R.Wirjono Prodjodikoro, Usep Ranawidjaja, R. Sri 
Soemantri Martosoewignjo, Ismail Suny, Padmo Wahjono, Bagir Manan, Jimly Asshiddiqie, Soehardjo Sastrosoehardjo, M.Solly Lubis, J.C.T. Simorangkir, I. Nyoman Dekker, Muhammad Ridwan Indra, Mohammad Mahfud MD., Dahlan Thaib, dan Chairul Anwar.

Namun demikian, meskipun telah cukup banyak uraian atau pembahasan mengenai Hukum Konstitusi dan telah terpenuhi persyaratan menjadi suatu ilmu yang berdiri sendiri, tetapi hingga saat ini perkembangannya baru dapat dikatakan pada tahapan Dasar-dasar Hukum Konstitusi, belum didudukkan sebagai Ilmu Hukum Konstitusi tersendiri. Untuk menjadi suatu Ilmu Hukum Konstitusi yang mandiri diperlukan pengkajian, pendalaman, penelitian, pembatangtubuhan pengetahuan, pengilmuan, profesionalisasi, pelembagaan, pertemuan-pertemuan ilmiah, publikasi ilmiah, dan pengimplementasian secara intensif dalam kerangka atau paradigma keilmuan Hukum Konstitusi.

Dengan kehadiran Ilmu Hukum Konstitusi sebagaimana terurai di atas, maka Ilmu Hukum Konstitusi dapat diposisikan ke arah suatu ilmu yang mandiri, sejajar dengan Ilmu-Ilmu Hukum normatif lain dalam lingkungan Ilmu HTN dalam arti luas yang meliputi tiga ilmu, yaitu Ilmu HTN dalam arti sempit dan Ilmu HTUN/HAN yang telah berkembang lebih dahulu, serta yang lahir kemudian Ilmu Hukum Konstitusi. Setelah melalui perkembangan tertentu, Ilmu Hukum Konstitusi bukan saja akan menjadi ilmu yang berdiri sendiri, bahkan akan menjadi induk dari semua cabang Ilmu-Ilmu Hukum Normatif. Ilmu Hukum Konstitusi akan membawahi dan memerintah Ilmu HTN dan Ilmu Hukum Biasa. Dalam Ilmu Hukum Biasa terdapat Ilmu HTUN/HAN, Ilmu Hukum Pidana, Ilmu Hukum Perdata, dan Ilmu Hukum Internasional.

\section{Alasan Memadai Kehadiran Ilmu Hukum Konstitusi}

Sebagai alasan memadai (ratio sufficiency) kehadiran Ilmu Hukum Konstitusi dapat dilihat dari terpenuhinya kualifikasi (persyaratan) untuk menjadi suatu ilmu yang berdiri sendiri, di mana persyaratan obyek, metode, nilai kegunaan, sistematis, logis, universal, pengertian-pengertian khusus, dan dukungan para ahli/ pakar Hukum Konstitusi semuanya sudah terpenuhi dan ke depan akan lebih maju lagi. 
Penyebab adanya (causa efficiency) Ilmu Hukum Konstitusi dapat dibagi ke dalam tiga penyebab, yaitu penyebab yuridis historis, penyebab yuridis eksisten, dan penyebab yuridis futuris.

\section{A. Penyebab yuridis historis}

Secara yuridis historis dapat menunjuk bahwa pengetahuan Hukum Konstitusi telah tumbuh sejak lama, persisnya sejak abad ke-4 sM yang dirintis oleh Aristoteles (384-322 sM) dengan penyelidikannya terhadap 158 konstitusi negara-negara kota (polis) dari 186 polis zaman Yunani kuno. Hasil penyelidikan tersebut, beliau tuangkan dalam buku Politeia (Politics). Terdapat empat bab yang berkenaan dengan konstitusi dari delapan bab dalam buku tersebut. Albert Venn Dicey (1835-1922) tahun 1885 meletakkan konstitusi ke dalam Pengantar Studi Hukum Konstitusi yang kemudian diikuti pengarang-pengarang berikutnya antara lain C.F.Strong dalam bukunya Modern Political Constitutions An Introduction to the Comparative Study of Their History and Existing Form (1930), Kenneth C.Wheare dalam bukunya Modern Constitutions (1951), Geoffrey Marshall dalam bukunya Constitutional Theory (1971), dan Astim Riyanto dalam bukunya Teori Konstitusi (1993). Keempat buku terakhir ini dapat dikategorikan ke dalam Dasar-dasar Hukum Konstitusi. Sejak 6 Agustus 2007 melalui presentasi makalah "Hukum Konstitusi Bagian Dari Hukum Tata Negara" di depan komunitas akademisi FPIPS UPI dalam rangka memperoleh Jabatan Guru Besar Tetap dalam Bidang Ilmu HTN spesialisasi Hukum Konstitusi yang dipimpin oleh Begawan Ilmu HTN Indonesia R.Sri Soemantri Martosoewignjo, setelah sekitar 122 tahun kemudian dari 1885 hingga 2007, saya mendeklarasikan Hukum Konstitusi sebagai suatu ilmu, yang berdiri sendiri dengan nama Ilmu Hukum Konstitusi.

\section{B. Penyebab yuridis eksisten}

Pada saat ini sejumlah negara di dunia mengalami atau menghadapi krisis konstitusi. Negara-negara yang mengalami atau menghadapi krisis konstitusi itu beberapa di antaranya sudah bubar, yaitu Uni Soviet, Yugoslavia, dan Cekoslovakia. Ketiga negara yang sudah bubar itu negara serikat, yaitu Uni Soviet dengan 16 negara bagian, Yugoslavia dengan 6 negara bagian, dan Cekoslovakia dengan 2 negara bagian. Beberapa negara lainnya yang tahun 2007 dapat 
dianggap negara-negara sedang mengalami krisis konstitusi antara lain "Rwanda, Somalia, dan Haiti". ${ }^{16}$ Krisis konstitusi yang dialami atau dihadapi oleh negara-negara, baik negara-negara yang sudah runtuh/bubar maupun negara-negara yang gagal dikarenakan tidak mendudukkan konstitusi sebagai hukum derajat tinggi atau hukum tertinggi dalam suatu negara sebagaimana mestinya. Hal itu disebabkan oleh banyak faktor yang dihadapi oleh suatu negara di antaranya : (1) kesulitan mencari atau menemukan landasan teori atau formula kenegaraan/ketatanegaraan yang adequate, (2) belum memiliki sistem kenegaraan/ketatanegaraan yang mampu mewadahi heterogenitas bangsa berdasarkan norma dasar (Grundnorm) negaranya, (3) makin kompleksnya permasalahan kenegaraan/ketatanegaraan, (4) menguatnya demokratisasi yang belum siap diwadahi dalam sistem hukum nasional yang ada, (5) pengaruh politik sektarian atau kelompok kepentingan yang mengabaikan keutuhan nasional, dan (6) politik kesejahteraan belum menjadi komitmen bersama.

\section{Penyebab yuridis futuris}

Dengan adanya Ilmu Hukum Konstitusi yang menyediakan teoriteori, asas- asas hukum/asas-asas peraturan perundang-undangan, dan cara-cara memformula norma-norma, model-model dan sub-submodel, pola-pola dan sub-subpola yang dihasilkan dari pengkajian-pengkajian dan penelitian-penelitian Hukum Konstitusi, maka negara-negara kesatuan dan negara-negara serikat dapat memanfaatkan hasil pengkajian-pengkajian dan penelitian-penelitian yang dilakukan oleh para ahli/pakar Hukum Konstitusi diberbagai negara dalam menghadapi masalah-masalah kenegaraan/ketatanegaraan. Dalam konteks ini terasa pentingnya dibentuk Asosiasi/ Ikatan Ahli/Pakar Hukum Konstitusi taraf Nasional setiap negara dan taraf Internasional untuk bekerja sama melakukan pengkajian-pengkajian dan penelitianpenelitian guna memecahkan masalah-masalah kenegaraan/ketatanegaraan yang dialami/dihadapi suatu negara atau beberapa negara.

${ }^{16}$ Lihat dan bandingkan Harian Umum Kompas, "Gagal Negara, Kekhawatiran Bisa Jadi Kenyataan", Jakarta, Jumat, 30 September 2005, hal. 77. 


\section{Karakteristik Hukum Konstitusi}

Baik sebagai ilmu maupun sebagai peraturan, Hukum Konstitusi memiliki karakteristik tertentu.

\section{A. Karakteristik Hukum Konstitusi sebagai Ilmu}

Secara umum Hukum Konstitusi sebagai ilmu, memiliki karakteristik: (1) hukum konstitusi masuk rumpun ilmu-ilmu sosial, (2) hukum konstitusi masuk ilmu-ilmu Hukum normatif, (3) hukum konstitusi masuk ilmu HTN dalam arti luas, (4) hukum konstitusi sebagai ilmu dengan obyek material konstitusi, (5) hukum konstitusi sebagai ilmu dengan obyek formal hukum dasar, (6) hukum konstitusi secara khusus menggunakan metode konstitutif, (7) hukum konstitusi memiliki nilai kegunaan teoretis dan kegunaan praktis memecahkan masalah-masalah kenegaraan/ ketatanegaraan, (8) hukum konstitusi memiliki batang tubuh pengetahuan konstitusi c.q. peraturan perundang-undangan terutama dalam lapangan ketatanegaraan, (9) hukum konstitusi tersusun logis dalam lapangan ketatanegaraan dan non ketatanegaraan yang terkait dengan lapangan ketatanegaraan, (10) hukum konstitusi sebagai ilmu mandiri memiliki pengertian-pengertian khusus, serta (11) hukum konstitusi memiliki ahli/pakar tersendiri.

\section{B. Karakteristik Hukum Konstitusi sebagai Peraturan}

Secara umum Hukum Konstitusi sebagai peraturan, memiliki karakteristik: (1) hukum konstitusi adalah hukum dasar, (2) hukum konstitusi adalah hukum derajat tinggi/hukum tertinggi, (3) hukum konstitusi adalah hukum pertama dan utama dalam suatu negara, (4) hukum konstitusi adalah hukum yang membentuk negara, (5) hukum konstitusi berisi lembaga-lembaga negara, (6) hukum konstitusi membatasi kekuasaan lembaga-lembaga negara, (7) hukum konstitusi memuat hak-hak dasar manusia dan warga negara, (8) hukum konstitusi merupakan sarana kontrol pelaksanaan peraturan di bawahnya, (9) hukum konstitusi bisa dalam arti formal/tertulis/bernaskah atau material/tidak tertulis/tidak bernaskah, (10) hukum konstitusi dalam arti umum dipergunakan pula oleh lembaga-lembaga non negara yang lazim pula disebut anggaran dasar, dan (11) konstitusi dapat difungsikan sebagai traktat (di negara serikat) atau non traktat (di negara kesatuan). 


\section{Implementasi Hukum Konstitusi}

Hukum Konstitusi ialah Hukum Dasar yang menetapkan dan mengatur organisasi Negara. Hukum Konstitusi sebagai ilmu secara aplikatif akan merefleksi ke dalam Hukum Konsitusi sebagai peraturan sebagai alat/sarana/instrumen dalam suatu institusi negara atau kenegaraan atau sosial akan merefleksi pula dalam pelaksanaannya tergantung pada banyak faktor. Secara umum dapat dibagi ke dalam dua faktor, yaitu faktor-faktor intern Hukum Konstitusi dan faktor-faktor ekstern Hukum Konstitusi. Dimaksud dengan faktor-faktor intern Hukum Konstitusi adalah faktor-faktor yuridis dari kualifikasi hukum atau norma-norma yang dibawa atau terkandung dalam peraturan Hukum Konstitusi dari efektivikasi hukum. Dimaksud dengan faktor-faktor ekstern Hukum Konstitusi adalah faktorfaktor filosofis dan sosiologis dari kualifikasi hukum dan faktor-faktor lembaga hukum, penegak/pelaksana hukum, fasilitas hukum, dan masyarakat hukum dari efektivikasi hukum.

Implementasi faktor-faktor intern berupa faktor-faktor yuridis dari kualifikasi hukum atau norma-norma dari efektivikasi hukum suatu peraturan Hukum Konstitusi akan ditentukan menurut nilai yang terkandung dalam faktor-faktor yuridis dari kualifikasi hukum atau norma-norma dari efektivikasi hukum suatu peraturan Hukum Konstitusi, yaitu apakah normanorma peraturannya memiliki nilai normatif, nilai nominal, atau nilai semantik dari suatu peraturan Hukum Konstitusi. Implementasi faktor-faktor ekstern norma-norma suatu peraturan Hukum Konstitusi akan ditentukan oleh faktor-faktor kekuasaan/kekuatan nyata yang ada dalam masyarakat. Agar tidak terjadi penyimpangan implementasi faktor-faktor yuridis dari kualifikasi hukum atau norma-norma suatu peraturan Hukum Konstitusi, karena kelemahan dalam norma-norma peraturannya, maka para pembentuk atau pengubah peraturan Hukum Konstitusi berpegang pada kekuatan sah, berlaku, dan mengikat atau kualitas norma-norma dalam pembentukan atau pengubahan Hukum Konstitusi ke arah Hukum Konstitusi yang memiliki kualitas memadai dan nilai normatif.

Supaya tidak terjadi penyimpangan yuridis atau norma-norma suatu peraturan Hukum Konstitusi, karena pengaruh teknis pembentukan suatu peraturan atau faktor-faktor kekuatan-kekuatan nyata yang ada dalam masyarakat, maka diperlukan lembaga-lembaga negara/pemerintah yang fungsional di bidangnya masing-masing dan saling mengimbangi, mengawasi, dan kemitraan satu sama lain. Dalam hal pengamanan konstitusi suatu negara, baik negara kesatuan maupun negara serikat terdapat lembaga negara yang ditugasi sebagai lembaga pengaman konstitusi ("the guardian of 
the constitution"). ${ }^{17}$ Di Indonesia sebagai negara kesatuan dengan desentralisasi, berdasarkan Perubahan Ketiga Undang-Undang Dasar Negara Republik Indonesia Tahun 1945 (UUD NRI 1945) tahun 2001 dan Pasal III Aturan Peralihan Perubahan Keempat UUD NRI 1945 tahun 2002 jo UU No. 24 Tahun 2003 tentang Mahkamah Konstitusi, lembaga peradilan yang berstatus lembaga negara ${ }^{18}$ yang secara khusus ditugasi sebagai pengaman UUD/Konstitusi adalah Mahkamah Konstitusi Republik Indonesia (MK RI).

Keberadaan MK RI mempunyai kedudukan dan peranan penting dalam penegakan Negara Hukum Indonesia yang diamanatkan Pasal 1 ayat (3) UUD NRI 1945 perubahan ketiga tahun 2001, yang berbunyi: "Negara Indonesia adalah negara hukum". Mengacu kepada tujuan negara RI yang termaktub dalam alinea keempat Pembukaan UUD NRI 1945 untuk "memajukan kesejahteraan umum", maka Negara Hukum tadi adalah Negara Hukum Kesejahteraan. Tugas berat MK RI khususnya Hakim Konstitusi tadi tercermin dari ketentuan Pasal $24 \mathrm{C}$ ayat (5) UUD NRI 1945 perubahan ketiga tahun 2001 yang mensyaratkan untuk menjadi Hakim Konstitusi harus memiliki integritas dan kepribadian negarawan yang menguasai konstitusi dan ketatanegaraan di samping persyaratan berat lainnya. Hal tersebut sejalan dengan beratnya penegakan Negara Hukum Kesejahteraan yang memiliki ciri-ciri utama atau unsur-unsur pokok, yaitu : (1) adanya konstitusi berdasarkan kedaulatan rakyat dan kedaulatan hukum, (2) adanya pemerintahan menjunjung tinggi hukum, (3) adanya persamaan di depan hukum, (4) adanya segala sesuatu diatur dengan hukum dan dijalankan menurut hukum, (5) adanya jaminan perlindungan hak-hak asasi manusia dan warga negara, (6) adanya pembagian dan pembatasan kekuasaan, (7) adanya pengutamaan manfaat penyelenggaraan negara, serta (8) adanya pemerintahan memajukan kemakmuran/kesejahteraan.

\section{Pengundangan dan Penyebarluasan Hukum Konstitusi}

Menyangkut pengundangan dan penyerbarluasan Hukum Konstitusi berkenaan dengan promulgasi, notifikasi, notifikasi melalui pendidikan,

${ }^{17}$ Lihat Jimly Asshiddiqie, "Perkembangan \& Konsolidasi Lembaga Negara Pasca Reformasi", Cetakan Kedua Oktober 2006 (Cetakan Pertama Februari 2006), (Jakarta: Konstitusi Press kerja sama dengan PT. Syaamil Cipta Media, 2006), hal. 154.

${ }^{18}$ Lihat Ikhsan Rosyada Parluhutan Daulay, "Mahkamah Konstitusi Memahami Keberadaannya Dalam Sistem Ketatanegaraan Republik Indonesia", Cetakan Pertama, PT. (Jakarta: Rineka Cipta, 2006), hal. 18-19. 
pendidikan hukum konstitusi melalui pendidikan kewarganegaraan, dan sumbangan pendidikan hukum konstitusi.

\section{A. Teori Promulgasi dan Notifikasi Hukum Konstitusi}

Dipandang dari segi teori, pengundangan/pengumuman (promulgasi, promulgation) Hukum Konstitusi dilakukan berdasarkan teori pengundangan/pengumuman atau teori promulgasi atau lengkapnya teori pengundangan/pengumuman peraturan perundangundangan (teori promulgasi legislasi, legislation promulgation theory). Pengundangan/pengumuman secara resmi diharuskan agar peraturan perundang-undangan mempunyai kekuatan hukum mengikat untuk menjamin kepastian hukum. Penyebarluasan (notifikasi, notification) Hukum Konstitusi dilakukan berdasarkan teori penyebarluasan atau teori notifikasi atau lengkapnya teori penyebarluasan peraturan perundang-undangan (teori notifikasi legislasi, legislation notification theory). Penyebarluasan diperlukan agar peraturan perundangundangan dipahami isi dan maksud yang terkandung di dalamnya untuk menunjang efektivikasi hukum.

\section{B. Promulgasi Hukum Konstitusi}

Dalam usaha memenuhi asas fiksi hukum "semua orang dianggap tahu hukum" dan "peraturan-peraturan yang telah dibuat harus diumumkan" untuk menjamin kepastian hukum dari suatu peraturan perundang-undangan, maka Hukum Konstitusi sebagai peraturan perundang-undangan melalui pengundangan/ pengumuman peraturan perundang-undangan (promulgasi legislasi, legislation promulgation) secara resmi dengan penempatannya dalam lembaran negara, berita negara, lembaran daerah, atau berita daerah. Untuk Indonesia, di tingkatan pusat, peraturan perundang-undangan yang diundangkan dengan menempatkannya dalam Lembaran Negara adalah UUD, UU/Perpu, PP, dan Perpres mengenai pengesahan perjanjian antara negara RI dan negara lain atau badan internasional dan pernyataan keadaan bahaya serta peraturan perundang-undangan lain yang menurut peraturan perundang-undangan yang berlaku harus diundangkan dalam Lembaran Negara RI.

Peraturan perundang-undangan lain yang menurut peraturan perundang-undangan yang berlaku harus diundangkan dalam Berita Negara RI. Tambahan Lembaran Negara RI memuat penjelasan peraturan perundang-undangan yang diundangkan dalam Lembaran Negara RI. Peraturan perundang-undangan lain yang menurut 
peraturan perundang-undangan yang berlaku harus diundangkan dalam Berita Negara RI. Tambahan Berita Negara RI memuat penjelasan peraturan perundang-undangan yang diundangkan dalam Berita Negara RI. Di tingkatan daerah, peraturan perundang-undangan yang diundangkan dalam Lembaran Daerah adalah Peraturan Daerah (Perda). Peraturan Gubernur, Bupati, dan Walikota atau peraturan lain di bawahnya diundangkan dalam Berita Daerah. Tambahan Lembaran Daerah memuat penjelasan peraturan perundang-undangan yang diundangkan dalam Lembaran Daerah. Dengan melalui pengundangan/pengumuman suatu peraturan perundang-undangan mempunyai kekuatan hukum mengikat untuk menjamin kepastian hukum.

\section{Notifikasi Hukum Konstitusi}

Agar khalayak ramai memahami isi dan maksud yang terkandung dalam peraturan perundang-undangan yang telah diundangkan/diumumkan secara resmi dalam lembaran negara, berita negara, lembaran daerah, atau berita daerah, ataupun penjelasannya yang telah dimuat dalam tambahan lembaran negara dan tambahan lembaran daerah, maka Pemerintah wajib melakukan penyebarluasan (notifikasi, notification) peraturan perundang-undangan Hukum Konstitusi sebagai peraturan perundang-undangan yang telah diundangkan dalam Lembaran Negara RI atau Berita Negara RI melalui penyebarluasan peraturan perundang-undangan (notifikasi legislasi, legislation notification). Pemerintah Daerah wajib melakukan penyebarluasan Perda yang telah diundangkan dalam Lembaran Daerah dan peraturan di bawahnya yang telah diundangkan dalam Berita Daerah. Penyebarluasan peraturan perundang-undangan, baik di tingkatan pusat maupun di tingkatan daerah dapat dilakukan melalui kegiatan-kegiatan sosialisasi (dari segi sosiologi) serta penempelan salinan peraturan pada papan-papan pengumuman, kegiatan-kegiatan penyuluhan, dan pemberitaan pada media massa cetak dan media massa elektronik (dari segi ilmu komunikasi). Dengan melalui penyebarluasan suatu peraturan perundang-undangan dipahami isi dan maksud yang terkandung di dalamnya untuk menunjang efektivikasi hukum.

\section{Notifikasi Hukum Konstitusi Melalui Pendidikan}

Di samping dari segi sosiologi dan segi komunikasi, notifikasi Hukum Konstitusi dapat dilakukan melalui pendidikan. Menurut Pasal 
1 angka 1 UU No.2 Tahun 1989 tentang Sistem Pendidikan Nasional (Sisdiknas), "Pendidikan adalah usaha sadar untuk menyiapkan peserta didik melalui kegiatan bimbingan, pengajaran, dan/atau latihan bagi peranannya di masa yang akan datang". Pendidikan Hukum Konstitusi ialah proses transfer bahan konstitusi dari pendidik kepada peserta didik guna memperoleh pengetahuan, sikap, dan keterampilan mengenai konstitusi berlandaskan teori-teori pendidikan, belajar mengajar (pembelajaran), dan psikologi perkembangan dengan metode didukung sumber belajar mengajar yang relevan. Melalui proses menanamkan pengetahuan, sikap, dan keterampilan mengenai bahan konstitusi termasuk sebagai hukum dasar dapat menegakkan Negara Hukum dalam menopang dan mengokohkan bangunan Negara. Notifikasi Hukum Konstitusi melalui pendidikan dapat melalui jalur pendidikan formal, pendidikan nonformal, dan juga pendidikan informal.

\section{E. Pendidikan Hukum Konstitusi Melalui Pendidikan Kewarganegaraan}

Notifikasi Hukum Konstitusi dapat dilakukan melalui Pendidikan Kewarganegaraan (PKn). Menurut Pasal 37 ayat (1) huruf b UU No. 20 Tahun 2003, kurikulum pendidikan dasar dan menengah wajib memuat PKn. Pasal 37 ayat (2) huruf b UU tersebut, menentukan kurikulum pendidikan tinggi wajib memuat PKn. Jadi, dalam kurikulum pendidikan formal, baik dalam kurikulum pendidikan dasar, kurikulum pendidikan menengah, maupun kurikulum pendidikan tinggi wajib memuat PKn. Dalam kurikulum pendidikan nonformal dan kurikulum pendidikan informal seperti pada sekolah rumah (home schooling) menyesuaikan sesuai dengan kebutuhan. Dalam PKn terdapat bahan Hukum Konstitusi. Oleh karena bahan Hukum Konstitusi berada dalam PKn, maka dapat diartikan bahan Hukum Konstitusi tersebut sebagai Pendidikan Hukum Konstitusi. Tegasnya Pendidikan Hukum Konstitusi dalam PKn.

Dalam PKn itu mengandung bahan konstitusi sebagai hukum dasar, hukum derajat tinggi, dan hukum tertinggi dalam suatu negara. Dengan demikian, kegiatan Pendidikan Konstitusi melalui jalur pendidikan formal dalam PKn dalam pengertian Civic Education atau dalam pelajaran lain yang relevan. Kegiatan Pendidikan Konstitusi melalui jalur pendidikan nonformal dan juga pendidikan informal dalam aktivitas PKn dalam pengertian Citizenship Education atau dalam aktivitas edukatif lain yang relevan. 


\section{F. Sumbangan Pendidikan Hukum Konstitusi}

Pendidikan Hukum Konstitusi dalam pencapaian tujuan PKn dalam lingkungan pendidikan formal dan pendidikan nonformal, juga dalam lingkungan pendidikan informal dapat memberikan sumbangan yang sesuai dengan kebutuhan nyata suatu negara dalam ranah kognitif, afektif, dan keterampilan (psikomotor).

Penguasaan atas bahan-bahan pembelajaran Hukum Konstitusi akan merambat ke dalam aktualisasi Hukum Konstitusi dalam suatu negara. Untuk Indonesia guna menegakkan/memperkuat : Norma Dasar Negara, Negara Konstitutional, Negara Kesatuan, Negara Hukum, Negara Kesejahteraan, Negara Demokrasi, Negara dengan Bentuk Pemerintahan Republik, Negara dengan Sistem Pemerintahan Presidensil, Negara dengan Desentralisasi, Negara dengan Desentralisasi yang Proporsional, dan Negara dengan Desentralisasi dengan bentuk Daerah Otonom. Melalui mata kuliah Hukum Konstitusi atau dengan nama lain di perguruan tinggi, pemahaman, penghayatan, dan pengamalan terhadap bahan-bahan pembelajaran Hukum Konstitusi lebih intens lagi.

\section{Peranan Ahli/Pakar Hukum Konstitusi}

Pada akhirnya maju-mundur, laju-mandeg, bahkan mati-hidupnya suatu pengetahuan dan suatu ilmu termasuk Hukum Konstitusi sangat tergantung pada dedikasi para ahli/pakar pendukungnya termasuk para ahli/pakar pendukung Hukum Konstitusi. Penulis berharap ke depan lebih banyak lagi para Sarjana Hukum di dalam dan luar negeri yang menekuni Hukum Konstitusi. Penulis juga berharap ke depan banyak pembukaan program-program studi atau setidaknya konsentrasi-konsentrasi studi Hukum Konstitusi pada program sarjana dan program pascasarjana; pembentukan lembaga-lembaga pengkajian dan penelitian Hukum Konstitusi; pembentukan asosiasi ahli Hukum Konstitusi, pemuatan artikel di media massa cetak/elektronik dan jurnal; penerbitan hasil penelitian dan buku-buku mengenai Hukum Konstitusi; pengurusan hak cipta hasil-hasil penelitian dan buku-buku mengenai Hukum Konstitusi; kerja sama penerbit-penerbit di Indonesia dan penerbit-penerbit di negara-negara lain dalam penterjemahan dan penyaduran buku-buku Hukum Konstitusi dari bahasa Indonesia ke bahasa asing dan sebaliknya agar buku-buku karangan ahli/pakar Indonesia masuk masyarakat global; penyelenggaraan pertemuan-pertemuan ilmiah seperti simposium, seminar, diskusi, diskusi panel, workshop, studium 
generale, sarasehan, penataran, lokakarya, dan sejenisnya yang melibatkan ahli-ahli/pakar-pakar Hukum Konstitusi dalam dan luar negeri.

Semuanya itu dilakukan dalam kerangka terbangunnya Negara Hukum Kesejahteraan. Diharapkan hasil pengkajian dan penelitian Hukum Konstitusi serta usaha lainnya yang sejenis dapat memberikan jalan bagi solusi masalah kenegaraan/ketatanegaraan berkenaan dengan norma dasar, hukum dasar, bentuk negara dan kenegaraan, pembentukan negara bangsa, bentuk pemerintahan, sistem pemerintahan, lembaga-lembaga negara/suprastruktur politik, badan-badan negara, hubungan antarlembaga negara, hubungan antarbadan negara, pembagian dan pembatasan kekuasaan/kewenangan lembaga-lembaga negara dan badan-badan negara, lembaga-lembaga infrastruktur politik, penyelenggaraan pemerintahan negara/nasional, penyelenggaraan negara hukum, penyelenggaraan negara kesejahteraan, perlindungan/penjaminan hak-hak asasi manusia, penyelenggaraan negara demokrasi, penyelenggaraan pemerintahan negara bagian dan pemerintahan lokal (untuk di negara serikat), penyelenggaraan pemerintahan daerah (untuk di negara kesatuan), dan sebagainya yang dihadapi oleh sejumlah negara, baik negara-negara serikat maupun negaranegara kesatuan.

\section{Penutup}

Hukum Konstitusi terdiri atas dua dimensi, yaitu Hukum Konstitusi sebagai ilmu dan Hukum Konstitusi sebagai peraturan. Hukum Konstitusi sebagai ilmu adalah bagian dari Ilmu Hukum Tata Negara, yang mempelajari konstitusi sebagai obyek material dan hukum dasar sebagai obyek formal. Hukum Konstitusi sebagai peraturan adalah bagian dari peraturan perundangundangan konstitutif dalam suatu negara atau suatu komunitas kenegaraan/ketatanegaraan. Hukum Konstitusi merupakan ilmu baru yang memusatkan perhatiannya kepada konstitusi sebagai hukum fundamental dalam memecahkan masalah-masalah kenegaraan/ ketatanegaraan. 


\section{Daftar Pustaka}

Achmad Sanusi, Pengantar Ilmu Hukum dan Pengantar Tata Hukum Indonesia, Bandung: CV. Tarsito, 1984.

Copi, Irving M., Introduction to Logics, Fifth Edition, New York: Macmillan Publishing Co., 1978.

Departemen Pendidikan dan Kebudayaan RI, Kamus Besar Bahasa Indonesia, Edisi Kedua, Cetakan Ketiga, Jakarta: PN. Balai Pustaka, 1994.

Dicey, Albert Venn, An Introduction to Study of The Law of The Constitution, Tenth Edition (First Edition 1885), London: English Language Book Society and Macmillan, 1952.

Godechot, Jacques, Les Constitutions de La France Depuis 1789, Paris: Garnier-Flammarion, 1982.

Ikhsan Rosyada Parluhutan Daulay, Mahkamah Konstitusi Memahami Keberadaannya Dalam Sistem Ketatanegaraan Republik Indonesia, Cetakan Pertama, Jakarta: PT. Rineka Cipta, 2006.

Jimly Asshiddiqie, Perkembangan \& Konsolidasi Lembaga Negara Pasca Reformasi, Cetakan Kedua Oktober 2006 (Cetakan Pertama Februari 2006), Jakarta: Konstitusi Press kerja sama dengan PT. Syaamil Cipta Media, 2006.

Maarseveen, Henc van and Ger van der Tang, Written Constitutions, A. Computerized Comparative Study, New York: Ocean Publications, Inc., Dobbs Ferry, 1978.

Max Boli Sabon, Fungsi Ganda Konstitusi Suatu Jawaban Alternatif Tentang Tepatnya Undang-Undang Dasar 1945 Mulai Berlaku, Bandung: PT. Grafttri, 1991.

Mundiri, Logika, Cetakan Ketiga (Cetakan Pertama 1994), Jakarta: PT. Raja Grafindo Persada, 1998.

Sri Soemantri Martosoewignjo, R., Prosedur dan Sistem Perubahan Konstitusi, Cetakan IV (Cetakan I 1978), Bandung: PT. Alumni, 1987.

Strong, C.F., Modern Political Constitutions An Introduction to the Comparative Study of Their History and Existing Form, Fifth (Revised) Edition 1958, Second Impression (First Printed 1930), London: Sidgwick \& Jackson Limited, 1960.

Thaib Thahir A.Mu'in, Ilmu Mantiq, Jakarta: Widjaya, 1966. 
Wheare, Kenneth C., Modern Constitutions, Third Impression (First Published 1951), Oxford University Press, London, New York, Toronto, 1975.

\section{Makalah}

Astim Riyanto, Hukum Konstitusi Bagian Dari Hukum Tata Negara, Makalah, Dipresentasikan di depan komunitas akademisi Fakultas Pendidikan Ilmu Pengetahuan Sosial (FPIPS) Universitas Pendidikan Indonesia (UPI) dalam rangka Dr.Astim Riyanto,SH,MH. memperoleh Jabatan Guru Besar Tetap dalam Bidang Ilmu Hukum Tata Negara spesialisasi Hukum Konstitusi pada FPIPS UPI di Bandung, Bandung, 6 Agustus 2007.

\section{Media Massa}

Harian Umum Kompas, "Gagal Negara, Kekhawatiran Bisa Jadi Kenyataan", Jakarta, Jumat, 30 September 2005.

\section{Peraturan Perundang-undangan}

Undang-Undang Dasar Negara Republik Indonesia Tahun 1945, Lembaran Negara 1959 Nomor 75.

Perubahan Kedua Undang-Undang Dasar Negara Republik Indonesia Tahun 1945, Ditetapkan oleh Majelis Permusyawaratan Rakyat RI tanggal 18 Agustus 2000.

Perubahan Ketiga Undang-Undang Dasar Negara Republik Indonesia Tahun 1945, Ditetapkan oleh Majelis Permusyawaratan Rakyat RI tanggal 9 November 2001.

Perubahan Keempat Undang-Undang Dasar Negara Republik Indonesia Tahun 1945, Ditetapkan oleh Majelis Permusyawaratan Rakyat RI tanggal 10 Agustus 2002.

Undang-Undang Republik Indonesia Nomor 20 Tahun 2003 tanggal 8 Juli 2003 tentang Sistem Pendidikan Nasional (Lembaran Negara RI 2003 No. 78, Tambahan Lembaran Negara RI No. 4301).

Undang-Undang Republik Indonesia Nomor 24 Tahun 2003 tanggal 13 Agustus 2003 tentang Mahkamah Konstitusi (Lembaran Negara RI 2003 No. 98, Tambahan Lembaran Negara RI No. 4316). 
Undang-Undang Republik Indonesia Nomor 10 Tahun 2004 tanggal 22 Juni 2004 tentang Pembentukan Peraturan Perundang-undangan (Lembaran Negara RI 2004 No. 53, Tambahan Lembaran Negara RI No. 4389).

Undang-Undang Republik Indonesia Nomor 32 Tahun 2004 tanggal 15 Oktober 2004 tentang Pemerintahan Daerah (Lembaran Negara RI 2004 No. 125, Tambahan Lembaran Negara RI No. 4437).

Peraturan Pemerintah Republik Indonesia Nomor 60 Tahun 1999 tanggal 24 Juni 1999 tentang Pendidikan Tinggi (Lembaran Negara RI 1999 No. 115, Tambahan Lembaran Negara RI No. 2860). 